\title{
Penggunaan Smartphone Sebagai Sumber Belajar Siswa Kelas XII IPS SMA Negeri 2 Lubuk Basung di Era Pandemi Pada Mata Pelajaran Sosiologi (Studi Kasus Kelas XII IPS 1, 2 dan 3)
}

\author{
Melda Novi Wati ${ }^{1}$, Desri Nora $A N^{2}$ \\ ${ }^{1,2}$ Universitas Negeri Padang \\ e-mail: noviwati.melda@yahoo.com, desrinora@ymail.com
}

\begin{abstract}
Abstrak
Penelitian ini dilatar belakangi oleh pemanfaatan smartphone sebagai sumber belajar siswa di era pandemi covid-19. Sebelum pandemi siswa juga sudah menggunakan smartphone sebagai sumber belajar. Namun, dengan kondisi seperti ini, smartphone menjadi pokok utama dalam proses pembelajaran. Penelitian ini bertujuan untuk mendeskripsikan (1) bagaimana penggunaan smartphone sebagai sumber belajar siswa kelas XII IPS di era pandemi ini, (2) kendala-kendala yang dialami siswa dan guru SMA Negeri 2 Lubuk Basung pada pembelajaran daring/Pembelajaran Jarak Jauh (PJJ). Metode penelitian yang digunakan adalah kualitatif dengan tipe studi kasus. Teknik pengumpulan data yang digunakan adalah observasi, wawancara secara daring dan dokumentasi. Subjek dari penelitian ini yaitu siswa kelas XII IPS dan guru mata pelajaran sosiologi. Teknik analisis data menggunakan reduksi data, penyajian data, verifikasi data dan penarikan kesimpulan. Hasil penelitian ini menunjukkan bahwa (1) penggunaan smartphone sebagai sumber balajar sangat bermanfaat bagi siswa karena banyak sumber yang didapatkan, (2) kendala dari siswa yaitu jaringan yang tidak stabil serta kurangnya pemahaman materi oleh siswa (3) kendala dari guru mata pelajaran karena jaringan dan guru tidak bisa memantau mana siswa yang berdiskusi dalam menyelesaikan tugas atau yang benar sendiri mengerjakannya.
\end{abstract}

Kata kunci: Kendala, Pandemi covid-19, Smartphone, Sumber belajar

\begin{abstract}
This research is motivated by the use of smartphones as a learning resource for students in the era of the Covid19 pandemic. Before the pandemic, students also used smartphones as a learning resource. However, under these conditions, smartphones are the main subject in the learning process. This study aims to describe (1) how the use of smartphones as a learning resource for class XII IPS students in this pandemic era, (2) the constraints experienced by students and teachers of SMA Negeri 2 Lubuk Basung in online learning / Distance Learning (PJJ). The research method used is qualitative with case study type. The data collection techniques used were observation, online interviews and documentation. The subjects of this study were students of class XII IPS and teachers of sociology subjects. Data analysis techniques used data reduction, data presentation, data verification and conclusion drawing. The results of this study indicate that (1) the use of smartphones as a learning resource is very beneficial for students because there are many sources obtained, (2) obstacles from students, namely unstable networks and a lack of understanding of the material by students (3) constraints from subject teachers due to networks and the teacher cannot monitor which students discuss completing the assignment or who do it themselves.
\end{abstract}

Keywords: Covid-19 pandemic, Learning resources, Obstacles, Smartphones

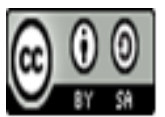

Received: October 15, 2020 Revised: November 11, 2020 Accepted: November 15, 2020 


\section{Pendahuluan}

Menurut (Daryanato 2004) international networking yang dapat disingkat internet merupakan dua komputer atau lebih yang saling berhubungan membentuk jaringan komputer hingga meliputi jutaan komputer didunia yanng saling berinteraksi dan bertukar informasi, sedangkan dari segi ilmu pengetahuan, internet merupakan sebuah perpustakaan besar didalamnya terdapat jutaan (bahkan milyaran) informasi atau data yang dapat berupa text, graphic, audio maupun animasi dan lain-lain dalam bentuk media cetak (Khaeriyah, 2017). Smartphone adalah mobile phone yang memiliki fungsi komputersisasi, pengiriman pesan, akses internet dan memiliki berbagai aplikasi sebagai sarana pencarian informasi seperti kesehatan, olahraga, uang, dan berbagai macam topik. Setiap smartphone memiliki sistem operasi yang berbeda-beda, sama halnya dengan sistem operasi pada komputer desktop (Brusco, 2010).

Indonesia adalah negara pengguna internet terbesar di Asia Tenggara. Internet di Indonesia saat ini sudah menjadi kebutuhan primer untuk para penggunanya, perkembangan sosial media juga menjadi salah satu faktor penting. Berdasarkan Survei Data Global Web Indeks, Indonesia adalah negara yang memiliki pengguna sosial media yang paling aktif di Asia. Indonesia memiliki 79,7\% user aktif disosial media mengalahkan Filipina, Malaysia $72 \%$, Cina 667\%. Data statistik perkembangan internet di Indonesia mencapai $15 \%$ atau 38.191873 pengguna internet dari total populasi kita 251.160.124, sedang pengguna internet dengan menggunakan gadget mencapai $14 \%$ dari populasi (Warisyah, 2015) Berdasarkan data yang diterima dari pegawai tata usaha SMA Negeri 2 Lubuk Basung mengenai penggunaan smartphone di sekolah. Dari 1.025 siswa-siswi di SMA Negeri 2 Lubuk Basung yang terdiri dari kelas X, XI, XII IPA dan IPS, umpamanya semua siswa yang memiliki smartphone. Untuk penggunaan smartphone sebagai sumber belajar dari setiap kelas hampir setiap siswa menggunakannya sebagai sumber tambahan belajar dari mata pelajaran yang dipelajari pada saat itu.

Pendidikan merupakan alat yang paling penting bagi suatu bangsa untuk mencari jati diri dan meningkat daya saing (Fernandes, 2017). Pendidikan bertujuan untuk mencerdaskan kehidupan bangsa juga sekaligus meningkatkan harkat dan martabat manusia. Melalui pendidikan itulah diharapkan dapat tercapai peningkatan kehidupan manusia kearah sempurna. Untuk mencapai hal itu, tentunya dalam menempuh pendidikaan diperlukan motivasi yang sangat besar, agar segala hambatan yang datang dapat diatasi. Pada dasarnya motivasi yang paling penting untuk pendidikan adalah sumber belajar yang banyak sehingga dapat meningkatkan hasil belajar (Alhafid \& Nora, 2020).

Tujuan pendidikan nasional Indonesia sesuai dengan Undang-Undang No. 20 Tahun 2003 yaitu, Pendidikan diupayakan dengan berawal dari manusia apa adanya (aktualisasi) dengan mempertimbangkan berbagai kemungkinan yang apa adanya (potensial), dan diarahkan menuju terwujudnya manusia yang seharusnya atau manusia yang dicita-citakan (idealitas). Tujuan pendidikan itu tiada lain adalah manusia yang beriman dan dan bertakwa kepada Tuhan YME, berakhlakmulia, sehat, cerdas, berperasaan, berkemauan, dan mampu berkarya; mampu memenuhi berbagai kebutuhan secara wajar, mampu mengendalikan hawa nafsu; berkepribadian, bermasyarakat, dan berbudaya. Implikasinya, pendidikan harus berfungsi untuk mewujudkan (mengembangkan) berbagai potensi yang ada pada manusia dalam konteks dimensi keberagaman, moralitas, individualitas/personalitas, sosialitas dan keberbudayaan secara menyeluruh dan terintegrasi. Dengan kata lain, pendidikan berfungsi untuk memanusiakan manusia (Sujana, 2019). Tujuan pendidikan ini tentunya juga sejalan dengan kurikulum yang berlaku di sekolah.

Covid-19 merupakan akronim dari coronavirus disease-2019. Coronavirus merupakan keluarga besar virus yang menyebabkan penyakit ringan sampai berat pada manusia, seperti common cold atau pilek dan penyakit yang serius seperti MERS dan SARS. Virus korona tipe baru yang

Jurnal Sikola: Jurnal Kajian Pendidikan dan Pembelajaran Vol. 2, No. 2, Th. 2020 
menjadi pandemic ini bernama SARS-CoV-2 (severe acute respiratory syndrome-coronavirus-2). Virus inilah yang menyebabkan Covid-19 (Adji, 2020). Covid-19 atau Corona Virus Deaseases mulai mewabah di Wuhan China pada Desember 2019. Penyebarannya semakin masif ke beberapa negara pada awal 2020 dan masuk ke Indonesia pada Maret 2020. Pada tanggal 11 Maret 2020 WHO menetapkan wabah ini sebagai pandemik global. Pandemi Covid-19 ini merupakan sebuah masalah yang memang meresahkan di seluruh belahan dunia. Dalam menangani penyebarannya pemerintah mengeluarkan beberapa kebijakan salah satu diantaranya dalam dunia pendidikan yaitu mengehentikan aktivitas di lingkungan kampus dan belajar mengajar dari rumah saja dengan Pembelajaran Daring.

Menteri Pendidikan Nadiem Anwar Makarim menerbitkan Surat Edaran Nomor 3 Tahun 2020 pada satuan pendidikan dan Nomor 36962/MPK.A/HK/2020 tentang Pelaksanaan Pendidikan dalam Masa Darurat Coronavirus Disease (covid-19) maka kegiatan belajar dilakukan secara daring (online) dalam rangka pencegahan penyebaran coronavirus disease (covid-19) (Dewi, 2020).

Menteri Pendidikan dan Kebudayaan Republik Indonesia pada tanggal 24 Maret 2020 mengeluarkan Surat Edaran Nomor 4 Tahun 2020 Tentang Pelaksanaan Kebijakan Pendidikan Dalam Masa Darurat Penyebaran COVID, dalam surat edaran tersebut dijelaskan bahwa proses belajar dilaksanakan dirumah melalui pembelajaran daring/jarak jauh dilaksanakan untuk memberikan pengalaman belajar yang bermakna bagi siswa. Belajar di rumah dapat difokuskan pada pendidikan kecakapan hidup antara lain mengenai pandemi Covid-19 (Dewi, 2020) . Sistem pembelajaran daring banyak menggunakan media online berupa aplikasi seperti classroom, google meet, dan zoom. Pembelajaran daring melalui aplikasi ini memudahkan siswa dan guru berinteraksi dalam berlangsungnya pembelajaran. Selain itu, media sosial juga digunakan untuk pembelajaran daring seperti whatsapp Group.

Menurut Gagne belajar adalah suatu proses dimana suatu organisme berubah perilakunya sebagai akibat pengalaman. Belajar dan mengajar merupakan dua konsep yang tidak dapat dipisahkan satu sama lain. dua konsep ini menjadi menjadi dalam satu kegiatan dimana terjadi interaksi antara guru dengan siswa, serta siswa dengan siswa pada saat pembelajaran berlangsung (Susanto, 2012).

Pembelajaran jarak jauh adalah pembelajaran ketika pengajar dan siswa tidak selalu hadir secara fisik secara bersamaan di sekolah (Setiawan, 2020). Pembelajaran yang dilakukan secara daring ini bertujuan untuk mengurangi kerumunan agar dapat menghentikan penyebaran virus corona. Penggunaan teknologi mobile mempunyai sumbangan besar dalam lembaga pendiddikan, didalamnya termasuk didalamnya adalah pencapaian tujuan pembelajaran jarak jauh (Sadikin, 2020).

\section{Metode Penelitian}

Jenis penelitian ini menggunakan pendekatan kualitatif, karena penelitian ini bertujuan untuk mendeskripsikan Penggunaan Smartphone Sebagai Sumber Belajar Siswa Kelas XII IPS SMA Negeri 2 Lubuk Basung pada saat pandemi covid-19. Penelitian kualitatif adalah penelitian yang ditujukan untuk mendeskripsikan dan menganalisis fenomena, peristiwa, aktivitas sosial, sikap, kepercayaan, persepsi, pemikiran orang secara individu maupun kelompok (Sukmadinata \& Syaudih, 2007). Tipe penelitian ini adalah studi kasus, data diperoleh dengan cara memahami individu yang dilakukan secara integrative dan komprehensif agar diperoleh pemahaman yang mendalam tentang individu tersebut beserta masalah yang dihadapinya dengan tujuan masalahnya dapat terselesaikan dan memperoleh perkembangan diri yang baik (Raharjo \& Gudnanto, 2011). Sehingga diperoleh gambaran yang menyeluruh dan mendalam tentang bagaimana penggunaan smartphone sebagai sumber belajar siswa kelas XII pada saat pandemi covid-19. 
Lokasi penelitian di SMA Negeri 2 Lubuk Basung karena selama peneliti telah melaksanakan Praktek Lapangan Kependidikan (PLK) hingga saat ini sudah menggunakan smartphone sebagai sumber belajar di sekolah sebelum adanya proses belajar daring. Dan disaat pembelajaran daring penggunaan smartphone sebagai sumber belajar pada mata pelajaran sosiologi menjadi sumber utama siswa dalam proses belajar. Pemilihan informan dalam penelitian ini dilakukan melalui purposive sampling. Teknik ini dipilih dengan pertimbangan bahwa peneliti telah memiliki gambaran terhadap orang-orang yang akan dijadikan informan dalam penelitian ini. Informan dalam penelitian ini siswa kelas XII IPS 1, XII IPS 2, dan XII IPS 3. Pada setiap kelas peneliti mengambil 5 siswa sebagai informan serta guru mata pelajaran Sosiologi di SMA Negeri 2 Lubuk Basung.

Teknik pengumpulan data yang digunakan dalam penelitian ini adalah observasi, wawancara secara daring, dan dokumentasi. Observasi yang peneliti lakukan adalah observasi non partisipan, dimana peneliti tidak langsung kegiatan yang dilakukan oleh informan.

Penelitian ini menggunakan analisis data dari model Miles dan Hubberman (Yusuf, 2014) yang terdiri dari tiga langkah, yaitu (1) reduksi data, (2) penyajian data, (3) penarikan kesimpulan. Dalam reduksi data, peneliti mempertajam, memilih, memfokuskan, membuang, dan mengorganisir data mengenai penggunaan smartphone sebagai sumber belajar siswa kelas XII ips 1, 2 dan 3 pada saat pandemi covid-19. Kemudian dalam penyajian data, peneliti menyajikan data secara sederhana sehingga mempermudah dalam penarikan kesimpulan. Selanjutnya pada penarikan kesimpulan, peneeliti mengumpulkan data-data hasil wawancara dan observasi mengenai penggunaan smartphone sebagai sumber belajar siswa kelas XII IPS SMA Negeri 2 Lubuk Basung pada saat pandemi covid-19.

\section{Hasil dan Pembahasan}

\section{Pemanfaatan Smartphone Sebagai Sumber Belajar}

Kualitas pelaksanaan pembelajaran di sekolah adalah pondasi awal keberhasilan proses Pendidikan (Sylvia, Anwar, \& Khairani 2019). Pembelajaran daring merupakan pembelajaran berbasis teknologi yang menggunakan aplikasi layanan berupa media online yang memang dirancang dan dibuat untuk dipergunakan dalam proses pembelajaran didunia pendidikan. Sistem pembelajaran daring banyak menggunakan media online berupa aplikasi seperti Classroom, Google Meet, dan Zoom. Pembelajaran daring melalui aplikasi ini memudahkan siswa dan guru berinteraksi dalam keberlangsungan pembelajaran. Selain itu, media sosial juga digunakan untuk pembelajaran daring seperti WhatsApp Group. Penelitian Hanifa Septiani memberikan bukti bahwa pengelolaan penggunaan smartphone yang baik dalam pembelajaran akan memerikan hasil yang signifikan terhadap disiplin belajar siswa (Septiani \& Sylvia, 2019).

Dari penelitian dengan informan, guru sosiologi di SMA Negeri 2 Lubuk Basung lebih sering menggunakan whatsapp group untuk memberi materi dan diskusi mengenai materi yang akan diajarkan dan penjelasan mengenai tugas yang akan dikerjakan. Namun, pembelajaran menggunakan google classrom hanya untuk pengambilan absen dan pengumpulan tugas, di google classroom tersebut siswa bisa melihat nilai yang diperoleh. Dari kedua aplikasi yang digunakan oleh guru sosiologi, lebih sering whatsapp group yang digunakan dalam pembelajaran daring.

Pembelajaran daring termasuk model pembelajaran yang berpusat pada siswa. Dengan demikian, siswa dituntut mandiri dan bertanggung jawab terhadap proses pembelajaran. Siswa harus bisa mengerti dan mengirimkan segala tugas yang sudah diberikan oleh guru meskipun terhalang banyak kendala. Disamping banyaknya aplikasi dan layanan pembelajaran daring yang disediakan masih saja menimbulkan sebuah masaalah yang terjadi pada siswa. Seperti banyaknya keluhan yang dirasakan oleh siswa mengenai belajar daring, yaitu mengenai materi yang tidak mereka pahami dan belum tersampaikan dengan jelas oleh guru. Dari hasil penelitian dengan informan, kendala yang dihadapi siswa dalam proses pembelajaran daring gangguan

Jurnal Sikola: Jurnal Kajian Pendidikan dan Pembelajaran Vol. 2, No. 2, Th. 2020 
jaringan didaerah pedesaan, belum lagi lampu mati, dan pembelian paket data yang banyak menghabiskan uang. Dan juga proses belajar sosiologi yang membutuhkan pemahaman konsep dan penjelasan dari guru secara langsung. Namun, guru sosiologi mengatasi hal tersebut dengan memberikan tugas dengan cara menganalisis fenomena dan kejadian sekitar yanng menyangkut dengan permasalahan sosiologi. Kendala lain yang dirasakan oleh siswa yaitu jaringan internet yang kurang lancar di daerah mereka. Terlebih lagi jika lampu di daerah mereka mati, maka secara otomatis jaringan internet mereka pun ikut hilang. Parahnya jika mereka sedang melakukan proses belajar pengambilan absen dan pengumpulan tugas yang diberikan waktu. Jika mereka telat untuk mengisi absen dan mengumpulkan tugas maka mereka dikatakan tidak hadir dan tugas mereka ada satu yang tidak membuat.

Siswa yang belajar daring harus memiliki kuota/paket data setiap harinya karena mereka akan selalu menerima dan mengirim tugas dari guru yang mengajar. Karena siswa harus menerima dan mengirimkan tugasnya, oleh karena itu siswa membutuhkan banyak kuota untuk mencari materi dan menerima serta mengirimkan tugas tersebut. Maka dari itu, tidak semua siswa yang bisa membeli kuota/paket data internetnya. Dari hasil penelitian, siswa kadangkadang bisa membeli paket internet, namun kadang-kadang juga tidak bisa. Apabila tidak bisa membeli internet mereka akan meminta hotspot dan atau mencuri wifi dari Rumah Sakit, Bank dan kantor lainnya. jika mereka memang tidak memiliki jaringan internet dirumah, maka mereka dapat mengambil dan mengumpulkan tugas ke sekolah.

Dapat disimpulkan kendala yang dialami oleh siswa yaitu jaringan internet yang tidak stabil. Sehingga tugas-tugas yang dikirim oleh guru terlambat masuk atau siswa terlambat mengirimkan tugas, hal ini berdampak siswa terlambat mendapatkan tugas dan mengirimkan tugas yang menyebabkan nilai bisa dikurangi. Sedangkan bagi guru sosiologi, Ibu Ewt (47 tahun) kendala yang dihadapi relatif sama dengan siswanya yaitu masalah jaringan internet dan guru tidak bisa memantau kolaborasi siswa saat mengerjakan tugas atau melakukan berdiskusi dalam suatu tempat atau berada dalam ruangan yang sama.

Sehubungan dengan pembelajaran daring yang dilakukan di tengah pandemi ini, dari pemerintahan berencana akan memberikan bantuan berupa pemberian kuota data internet. Menteri pendidikan dan Kebudayaan (Mendikbud) Nadiem Anwar Makarim meresmikan kebijakan bantuan kuota data internet tahun 2020, secara virtual, Jumat (24/09). Kebijakan ini diharapkan dapat membantu akses informasi bagi guru, bagi guru, siswa, mahasiswa, dan dosen dalam menjalani Pembelajaran Jaraj Jauh (PJJ) selama masa pandemi.

Dengan berita adanya pemberian kuota data internet dari Pemerintah, Sebagai sekolah yang juga melakukan Pembelajaran Jarak jauh (PJJ) SMA Negeri 2 Lubuk Basung segera mendaftarkan nomor ponsel peserta didik kepada Dinas Pendidikan dan Kebudayaan Dari pihak sekolah sendiri mengatakan, di wakili oleh Wakil Kurikulum Ibu Irdawati umur 55 tahun, yaitu:

"Kami dari pihak sekolah sudah mengirim nomor-nomor Hp siswa ke Dinas Pendidikan dan Kebudayaan di Padang. Tapi belum mendapatkan konfirmasi dari pihak Dinas terkait dengan pemberian kuota belajar kepada para siswa. Dari hasil penelitian, rata-rata informan menerima kuota data gratis yang diberikan oleh Pemerintah. Namun tidak sekaligus, pemnerimaan kuota data gratis tersebut bertahap mereka dapatkan. Jumlah kuota data internet yang didapat siswa dari pemerintah yaitu $35 \mathrm{~GB} /$ bulan, dengan rincian 5 GB untuk kuota umum dan 30 GB untuk kuota belajar. Bagi kami yang mendapatkan kuota data gratis ini bersyukur karena telah membantu kami untuk tidak membeli paket data sehingga mengurangi pengeluaran biaya orangtua".

Walaupun tidak semua siswa yang mendapatkan kuota data gratis ini, nantinya pembagian kuota gratis bertahap dilakukan oleh pemerintah. Penyaluran kuota subsidi tersebut dilakukan selama empat (4) bulan, yakni dimulai pada September hingga Desember 2020 dengan jadwalnya yaitu, bantuan kuota data internet di bulan September tahap I pada 22-24 September 2020. Tahap II pada 28-30 september 2020. Bantuan kuota data internet untuk bulan Oktober,

Jurnal Sikola: Jurnal Kajian Pendidikan dan Pembelajaran Vol. 2, No. 2, Th. 2020 
tahap Idimulai pada 22-24 Oktober 2020. Tahap II yakni pada tanggal 28-30 Oktober 2020. Sedangkan pada tahap akhir bantuan kuota data internet untuk November dan Desember akan dikirim secara bersamaan dengan jadwal tahap I pada 22-24 November 2020. Sementara untuk tahap II dimulai pada 28-30- November 2020 .

Dalam pembelajaran daring, jika siswa diberikan tugas oleh guru mereka dapat mencari jawabannya dari berbagai sumber belajar yang ada di internet, buku dan penjelasan yang telah diberikan oleh guru. Namun, banyak dari mereka lebih menggunakan internet sebagai sumber belajar utama dalam penyelesaian tugas dan materi dari guru menjadi sumber sekunder. Biasanya untuk menambah ilmu pengetahuan mereka, siswa mengakses internet dan aplikasi belajar yang memungkinkan untuk mendapatkan ilmu tambahan. Aplikasi yang biasa siswa akses yaitu google, quizzes, brainly, ruang guru, zenius, dan youtube yang memunculkan video pembahasan mengenai materi yang akan dicari. Aplikasi quizzes ini memberikan kemudahan bagi siswa untuk membahas dan menjawab soal-soal. Sehingga siswa lebih mudah untuk memahami materi sosiologi yang membutuhkan pemahaman lebih. Walaupun guru belum menjelaskan secara jelas, tapi dengan adanya smartphone ini dapat membantu siswa untuk mencari tambahan materi pelajaran. Semua ini juga tergantung dari diri siswa sendiri, jika mereka tidak memilah dari penjelasan yang mereka dapatkan dari internet, maka siswa bisa salah tangkap terhadap materi dari internet tersebut. Itu kembali lagi pada diri masing-masing siswa.

\section{Adaptation (adaptasi)}

Adaptation atau adaptasi adalah suatu sistem yang harus menanggulangi situasi eksternal yang gawat. Sistem harus menyesuaikan diri dengan lingkungan dan menyesuaikan lingkungan itu dengan kebutuhannya. Sejak dikeluarkannya Surat Edaran Nomor 4 tentang pelaksanaan kebijakan pendidikan dalam masa darurat penyebaran coronavirus disease (covid-19) oleh Menteri Pendidikan dan Kebudayaan Republik Indonesia, SMA Negeri 2 Lubuk Basung mengeluarkan kebijakan untuk melaksanakan proses belajar mengajar dirumah atau secara virtual. Oleh karena itu, guru dan siswa harus mampu menyesuaikan diri dengan kebijakan tersebut. Dalam pelaksanaan proses belajar secara daring, siswa dan guru menggunakan Whatsapp, Google Classroom, Zoom, Google Meet dan link web yang disediakan oleh pihak sekolah. Oleh karena ini guru harus mampu menggunakan berbagai aplikasi terutama dalam pembelajaran sosiologi yang menuntut keaktifan dan kemampuan siswa untuk berpikir kritis. Dan para siswa pun harus bisa menyesuaikan keadaan belajar secara daring ini agar materi yang disampaiakn oleh guru mata pelajaran dapat tersampaikan dengan jelas dan benar.

Dari guru pelajaran sosiologi pun menyatakan, siswa akan lebih paham dengan materi yang diberikan secara langsung melalui classroom dan nantinya akan dibahas di whatsapp group secara mendetail. Untuk lebih dipahami siswa, guru memberikan tugas berupa penjelasan fenomena dan kejadian lingkungan tempat tinggal yang berkaitan dengan materi pelajaran sosiologi. Dan guru mengirimkan bahan ajar berupa video-video pembelajaran, yang membuat siswa merasa lebih paham.

\section{Goal Attainment (pencapaian tujuan)}

Goal attainment atau pencapaian tujuan adalah sebuah sistem harus mendefinisikan dan mencapai tujuan utamanya. Setiap tindakan manusia memiliki tujuan yang hendak dicapai. Akan tetapi tujuan individu seringkali bertentangan dengan tujuan-tujuan lingkungan sosial.

Tujuan dari SMA Negeri 2 Lubuk Basung menerapkan proses belajar secara daring (online) agar pembelajaran tetap berlangsung sesuai dengan kurikulum. Kemudian tujuan siswa menggunakan smartphone sebagai sumber belajar pada mata pelajaran sosiologi di era pandemi ini agar materi yang diberikan guru dapat mereka gali lebih dalam lagi menggunakan informasi yang mereka dapat dari internet melalui smartphone mereka. Tujuan dari siswa menggunakan

Jurnal Sikola: Jurnal Kajian Pendidikan dan Pembelajaran Vol. 2, No. 2, Th. 2020 
smartphone mereka sebagai sumber belajar pun berpengaruh terhadap keberhasilan siswa dalam memahami materi. Untuk itu siswa harus bisa menelaah kata-kata dari internet supaya sejalan dengan materi yang disampaikan guru. Agar tujuan dari pembelajaran daring dengan menggunakan smartphone sebagai sumber belajar dapat tercapai.

\section{Integration (integrasi)}

Integration atau integrasi adalah sebuah sistem harus mengatur hubungan antar bagianbagian yang menjadi komponennya. Sistem juga harus mengelola antarhubungan ketiga fungsi penting lainnya (A, G, L). Konsep integrasi menunjukkan adanya bagian dari solidaritas sosial yang membentuk serta berperannya masing-masing unsur tersebut sesuai dengan posisi dan statusnya. Ikatan solidaritas akan menjadi berantakan apabila masing-masing unsur yang membentuk suatu sistem itu memperlihatkan atau mengedepankan kepentingan masing-masing.

Penggunaan smartphone sebagai sumber belajar di era pandemi ini membentuk siswa mencari sumber belajar lebih dari internet daripada hanya mendapatkan dari guru atau sumber buku yang kurang paham dikarenakan keterbatasan waktu dan tempat yang tidak memungkinkan bagi terlaksanakan pembelajaran sosiologi.

\section{Latency (pemeliharaan pola)}

Latency atau pemeliharaan pola adalah sebuah sistem harus melengkapi, memelihara, dan memperbaiki baik motivasi individu maupun pola-pola culture yang menciptakan dan menopang motivasi. Pihak sekolah, para guru,staff dan seluruh siswa sama-sama menjalankan proses pembelajaran berdasarkan peraturan yang berlaku pada saat ini. Siswa juga menjalankan dan memelihara keberhasilan pembelajaran daring dengan memanfaatkan smartphone mereka sebagai sumber belajar. Dan guru pun memotivasi siswa dengan memberikan pelajaran dengan levih variatif dan kreatif supaya siswa tidak bosan lebih memahami materi.

\section{Kesimpulan}

Dari hasil penelitian yang telah peneliti lakukan, dapat disimpulkan bahwa peggunaan smartphone sebagai sumber belajar memiliki kemudahan bagi siswa dalam mendapatkan tambahan pelajaran yang kurang dipahami dari penjelasan guru. Namun, juga memiliki kendala, yaitu jaringan yang kurang lancar di daerah tertentu, jika lamou mati jaringan pun ikut menghilang. Belum lagi jika banyak tugas yang dikirimkan oleh guru, smartphone bisa heng karena kebanyakan menerima file dan chat whatssapp group dari kelas mata pelajaran. Dengan pembelajaran seperti ini siswa mengatakan kurang efektif karena mereka sulit untuk memahami materi yang dikirimkan oleh guru mata pelajaran. Guru yang mengajar pun memiliki kendala yang sama dengan siswa, yaitu jaringan yang susah dan materi yang tidak tersampaikan dengan baik kepada siswa. Sehingga membuat siwa tidak paham dan mengerti dengan pembelajaran.

\section{Daftar Pustaka}

Adji, N. (2020). Bahasa Indonesia di Belantara Istilah Asing Terkait Covid-19. https://bebas.kompas.id/baca/opini/2020/04/11/bahasa-indonesia-di-belantara-istilahasing-terkait-covid-19/

Alhafid, A. F., \& Nora, D. (2020). Kontribusi Dukungan Sosial Orang Tua dan Peran Teman Sebaya Terhadap Hasil Belajar Sosiologi Siswa kelas X dan XI di SMA Negeri 2 Bengkulu Selatan. Jurnal Sikola: Jurnal Kajian Pendidikan dan Pembelajaran, 1(4), 284-300.

Brusco, J. M. (2010). Using Smartphone Appication In Perioperative Practive. AORN, 92(5), 503-508.

Dewi, W. A. F. (2020). Dampak Covid-19 terhadap implementasi pembelajaran daring di 
Sekolah Dasar. Edukatif: Jurnal Ilmu Pendidikan, 2(1), 55-61.

Fernandes, R. (2017). Adaptasi Sekolah Terhadap Kebijakan Pendidikan Inklusif. Socius: Journal of Sociology Research and Education, 4(2), 119-125. https://doi.org/10.24036/scs.v4i2.16

Khaeriyah, A. M. (2017). Pengaruh Intensitas Penggunaan Smartphone Dan Pemanfaatan Terhadap Motivasi Belajar Ekonomi. Skripsi. Universitas Negeri Semarang.

Raharjo, S., \& Gudnanto. (2011). Pemahaman Individu Teknik Non Tes. Kudus: Nora Media Enterprise.

Sadikin, A., \& Hamidah, A. (2020). Pembelajaran Daring di Tengah Wabah Covid-19: (Online Learning in the Middle of the Covid-19 Pandemic). Biodik, 6(2), 214-224.

Septiani, H., \& Sylvia, I. (2019). Hubungan Intensitas Penggunaan Smartphone Dengan Disiplin Belajar Siswa Kelas X SMA 2 Pariaman. Jurnal Sikola: Jurnal Kajian Pendidikan dan Pembelajaran, 1(1), 80-90. https://doi.org/10.24036/sikola.v1i1.12

Setiawan, A. (2020). Lembar Kegiatan Literasi Saintifik untuk Pembelajaran Jarak Jauh Topik Penyakit Coronavirus 2019 (covid-19). Edukatif: ilmu pendidikan, 2 nomor 1, 28-37.

Sujana, I.W.C. (2019). Fungsi dan Tujuan Pendidikan Indonesia. Adi Widya: Jurnal Pendidikan Dasar, 4(1), 1-10.

Sukmadinata, \& Syaudih, N. (2007). Metode Penelitian Pendidikan. Bandunng: PT. Remaja Rosdakarya.

Susanto, A. (2012). Teori Pembelajaran di Sekolah Dasar. Jakarta: Kencana.

Sylvia, I., Anwar, S., \& Khairani, K. (2019). Pengembangan Instrumen Penilaian Autentik Berbasis Pendekatan Authentic Inquiry Learning Pada Mata Pelajaran Sosiologi di Sekolah Menengah Atas. Socius: Journal of Sociology Research and Education, 6(2), 103-120. https://doi.org/10.24036/scs.v6i2.162

Warisyah, Y. (2019, June). Pentingnya "Pendampingan Dialogis" Orang Tua Dalam Penggunaan Gadget Pada Anak Usia Dini. Seminar Nasional Pendidikan 2015.

Yusuf, M. (2014). Metode Penelitian Kuantitatif, Kualitatif dan Gabungan. Jakarta: Kencana. 